\title{
White spruce growth to age 44 in a provenance test at the Petawawa Research Forest
}

\author{
by Kristian Morgenstern ${ }^{1}$, Steve D'Eon² and Margaret Penner ${ }^{3}$
}

\begin{abstract}
Twenty-five provenances of white spruce were planted in 1963 in 144-tree plots and three replications as part of a provenance test series for eastern Canada. The experiment was well maintained and thinned to $50 \%$ of its original stocking in 1986 (age 26 years from seed). Measurements at age 44 were subjected to analyses of variance and correlation and compared with height and survival at age 15 . The results demonstrated that at age 15 , identification of the best provenances is ineffective because of changes in rank and the late expression of survival differences. At age 44, significant differences among provenances were observed for survival, mean height, diameter, basal area, and volume. The greatest volume was produced by a provenance from Cushing in the Ottawa Valley in Quebec, $287 \mathrm{~m}^{3}$ per ha, which was $11 \%$ greater than the volume of the local provenance, Chalk River, Ontario. When ranked on the basis of survival and volume, the best eight provenances included five from Quebec, and one each from New Brunswick, Ontario, and Wisconsin. The experiment shows that at the appropriate stage in a selection program, large plots can yield significant results, which has important implications for the design of experiments.
\end{abstract}

Key words: provenance tests, jack pine, experimental design, growth and yield

\section{RÉSUMÉ}

Vingt-cinq provenances d'épinette blanche ont été plantées en 1963 dans 144 parcelles suivant une triple répétition en tant qu'éléments d'une série de test de provenance dans l'est du Canada. Le site expérimental a été bien entretenu et éclairci à 50\% de son niveau original de tiges par hectare en 1986 (à 26 ans à partir de la semence). Les mesures effectuées à l'âge de 44 ans ont été soumises à des analyses de variance et de corrélation et comparées avec la hauteur et la survie à l'âge de 15 ans. Les résultats démontrent qu'à l'âge de 15 ans, l'identification des meilleures provenances est inefficace par suite des changements de rangs et de l'expression tardive des différences de survie. À l'âge de 44 ans, des différences significatives entre les provenances ont été observées au niveau de la survie, de la hauteur moyenne, du diamètre, de la surface terrière et du volume. Le plus important volume a été produit par une provenance issue de Cushing dans la Vallée de l'Outaouais au Québec, soit $287 \mathrm{~m} 3$ par ha, ce qui était supérieur de $11 \%$ au volume de la provenance locale, Chalk River en Ontario. Une fois classées selon la survie et le volume, les huit meilleures provenances comprenaient cinq du Québec et une chacune pour le Nouveau-Brunswick, l'Ontario et le Wisconsin. L'essai démontre qu'au moment approprié d'un programme de sélection, les grandes parcelles peuvent démontrer des résultats significatifs ce qui entraînent des implications importantes au niveau de la conception des essais.

Mots clés : tests de provenance, pin gris, design expérimental, croissance et rendement

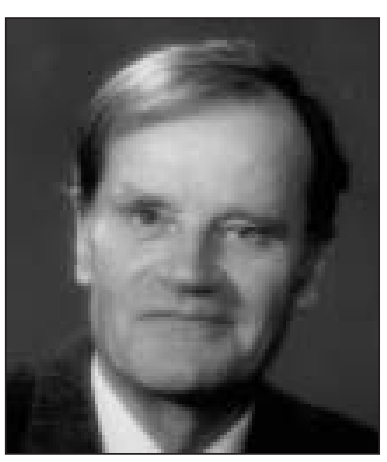

Kristian Morgenstern

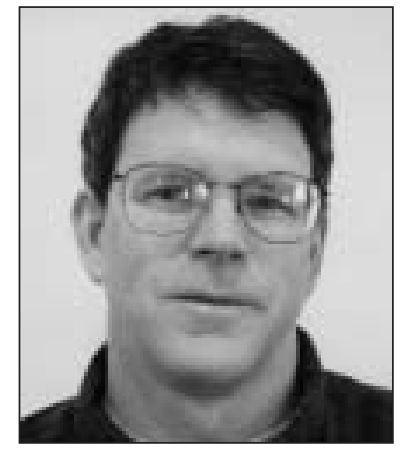

Steve D'Eon

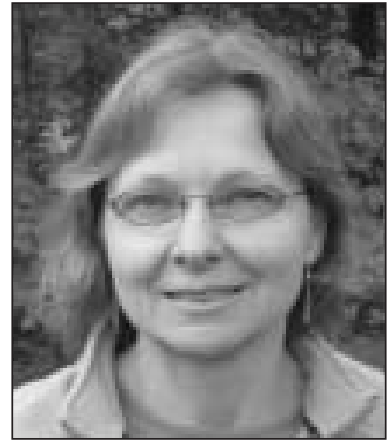

Margaret Penner

\footnotetext{
${ }^{1}$ Former Research Scientist at Petawawa and retired Professor, University of New Brunswick, now at R.R. 7, Pembroke, Ontario K8A 6W8. ${ }^{2}$ Manager, Petawawa Research Forest, Canadian Forest Service, Natural Resources Canada, P.O. Box 2000, Chalk River, Ontario K0J 1J0. Author to whom correspondence should be sent. E-mail: sdeon@NRCan.gc.ca

${ }^{3}$ Forest Analysis Ltd., R.R. 4, Huntsville, Ontario P1H 2J6.
} 


\section{Introduction}

Studies of geographic variation in forest trees have covered a broad field of activities ranging from fundamental biosystematic and genecological research to more applied seed source or provenance studies. Biosystematics and genecology are usually explored in short-term experiments conducted in controlled environments such as greenhouses and nurseries by observing juvenile characteristics and phenology. In experiments with a hierarchical structure including populations (stands grouped by regions), subpopulations (stands within regions), and families of half-sibs (progenies of individual trees), genetic variances can be obtained in a very efficient manner from hundreds of seedlots in a relatively small area, and the responses related to climate and other factors of the place of seed origin. The results lend themselves to develop seed zones and rules for seed transfer (Morgenstern 1969, Beaulieu et al. 2004, Rehfeldt 2004).

In contrast, provenance studies designed to meet the needs of plantation silviculture (often constituting the second phase in a research program), require field tests with larger areas, more financial resources, and longer time periods before significant results appear. Such studies can be justified on the basis of information obtained on long-term adaptation and survival, resistance to climatic extremes and insects and diseases, wood quality, and volume production per unit area. The general rule is that half a rotation period must elapse before reliable results can be obtained (Schober 1961). It has been shown that often long-term survival is a critical factor and can disqualify early results because of minor differences in adaptation such as inadequate synchronization of the tested populations' seasonal development with the climate of the test area, which gradually accumulate over time and become very significant at the end (Silen 1978, Oleksyn and Giertych 1984). However, the design of such long-term experiments is critical (Cochrane and Cox 1957, Loo-Dinkins 1992).

Experiment 194-D-1 at the Petawawa Research Forest is a 4.6-ha white spruce (Picea glauca (Moench) Voss) test plantation, part of a provenance experiment designed by the late Mark Holst in 1958. It is part of a series of six tests, which were arranged in a transect across the province of Ontario from Fort Frances in the northwest to Owen Sound in the south, and planted in 1963 (Holst 1958). Although the location, layout and maintenance of this series with very large plots proved to be difficult, and most of the tests have only been measured once (Teich et al. 1975), the Petawawa test is in good condition and is contributing valuable data as will be shown in this paper.

\section{Materials and Methods}

During the winter of 1953-54 plans were made for a comprehensive white spruce provenance experiment that sampled the Great Lakes - St. Lawrence Forest Region (Rowe 1959). The Woodlands Section of the Canadian Pulp and Paper Association was contacted and promised support, and the provincial forest services of Ontario and Quebec, the U.S. Forest Service, and the University of Toronto also cooperated (Holst 1958). Seed collections were made in 75 natural stands primarily in 1956, a good seed year. The seed was divided into three parts, a western series with 25 provenances to be grown in Ontario, an eastern series with 25 provenances for Quebec,
New Brunswick and Newfoundland, and a combined series with 49 provenances for Ontario, Quebec and New Brunswick (Holst 1958, Corriveau and Boudoux 1971, Teich 1973). In this report only the Petawawa test plantation of the western series can be discussed (Exp. 194-D-1) because results from the other tests are not available and most have been abandoned. The 25 seedlots with their places of origin and latitudes and longitudes are given in Table 1 and a map of their origins in Fig. 1.

The seed was sown in the Petawawa tree breeding nursery in the spring of 1959, seedlings transplanted two years later in the nursery, and the resulting 2-2 stock outplanted in the spring of 1963. The test area is a former hardwood site with a fairly deep acidic till soil of medium fertility and level topography. The experimental design consisted of square plots with 12 rows of 12 trees each planted at $1.8 \times 1.8 \mathrm{~m}$ spacing in a $5 \times 5$ balanced lattice square with three replications. In this design, rows and columns of the basic plan are randomized so that neighbourhoods of the same provenances are more often avoided than in randomized-block experiments, making the experiment more efficient (Cochrane and Cox 1957). Plots were separated by single division rows, and two surround rows formed the outside border, again all trees planted at 1.8$\mathrm{m}$ spacing. These large ( $0.04 \mathrm{ha})$ plots were adopted to meet the requirements for long-term observation and determination of volume differences. Although very unusual in dimension in comparison with many other experiments, they approximately agreed with an expert's recommendation to use plots of 0.05 ha with conifers for a test period of 35 to 40 years in northern climates (Schober 1961).

Table 1. Provenance origin by seedlot number

\begin{tabular}{lllcc}
\hline \multirow{2}{*}{$\begin{array}{l}\text { Seedlot } \\
\text { No. }\end{array}$} & Location & $\begin{array}{l}\text { Province } \\
\text { or State }\end{array}$ & $\begin{array}{c}\text { Lat. } \\
\text { N. }\end{array}$ & $\begin{array}{c}\text { Long. } \\
\text { W }\end{array}$ \\
\hline 2438 & Cobourg & Ontario & 44.1 & 78.0 \\
2445 & Cushing & Québec & 45.6 & 74.5 \\
2447 & Grandes-Piles & Québec & 46.7 & 73.1 \\
2454 & Lac Baskatong & Québec & 47.0 & 75.6 \\
2458 & Bissett Creek South & Ontario & 46.2 & 78.1 \\
2462 & Lac McNally & Québec & 46.5 & 76.5 \\
2463 & Notre-Dame-du-Laus & Québec & 46.0 & 75.4 \\
2464 & Chalk River & Ontario & 45.9 & 77.4 \\
2466 & Manitoulin Island & Ontario & 45.8 & 82.9 \\
2467 & Miller Lake & Ontario & 45.0 & 81.3 \\
2472 & Price & Québec & 48.2 & 67.8 \\
2473 & Edmundston & New Brunswick & 47.4 & 68.2 \\
2477 & Ashley Mines & Ontario & 48.0 & 81.0 \\
2480 & Kakabeka Falls & Ontario & 48.5 & 89.5 \\
2483 & Pagwachuan Lake & Ontario & 49.7 & 86.1 \\
2484 & Lac Mitchinamecus & Québec & 47.4 & 75.1 \\
2486 & Swastika & Ontario & 48.1 & 80.1 \\
2491 & Valcartier & Québec & 46.9 & 71.5 \\
2570 & Chequamegon Nat. For. & Wisconsin & 46.8 & 91.0 \\
2571 & Grand Rapids & Minnesota & 47.5 & 94.0 \\
2572 & Huron Nat. For. & Michigan & 44.5 & 83.7 \\
2601 & Cook County & Minnesota & 47.7 & 90.1 \\
2602 & Luce County & Michigan & 46.7 & 85.3 \\
2603 & Marquette County & Michigan & 46.1 & 87.6 \\
2604 & Rivière Shipshaw & Québec & 48.7 & 71.1 \\
\hline & & & &
\end{tabular}




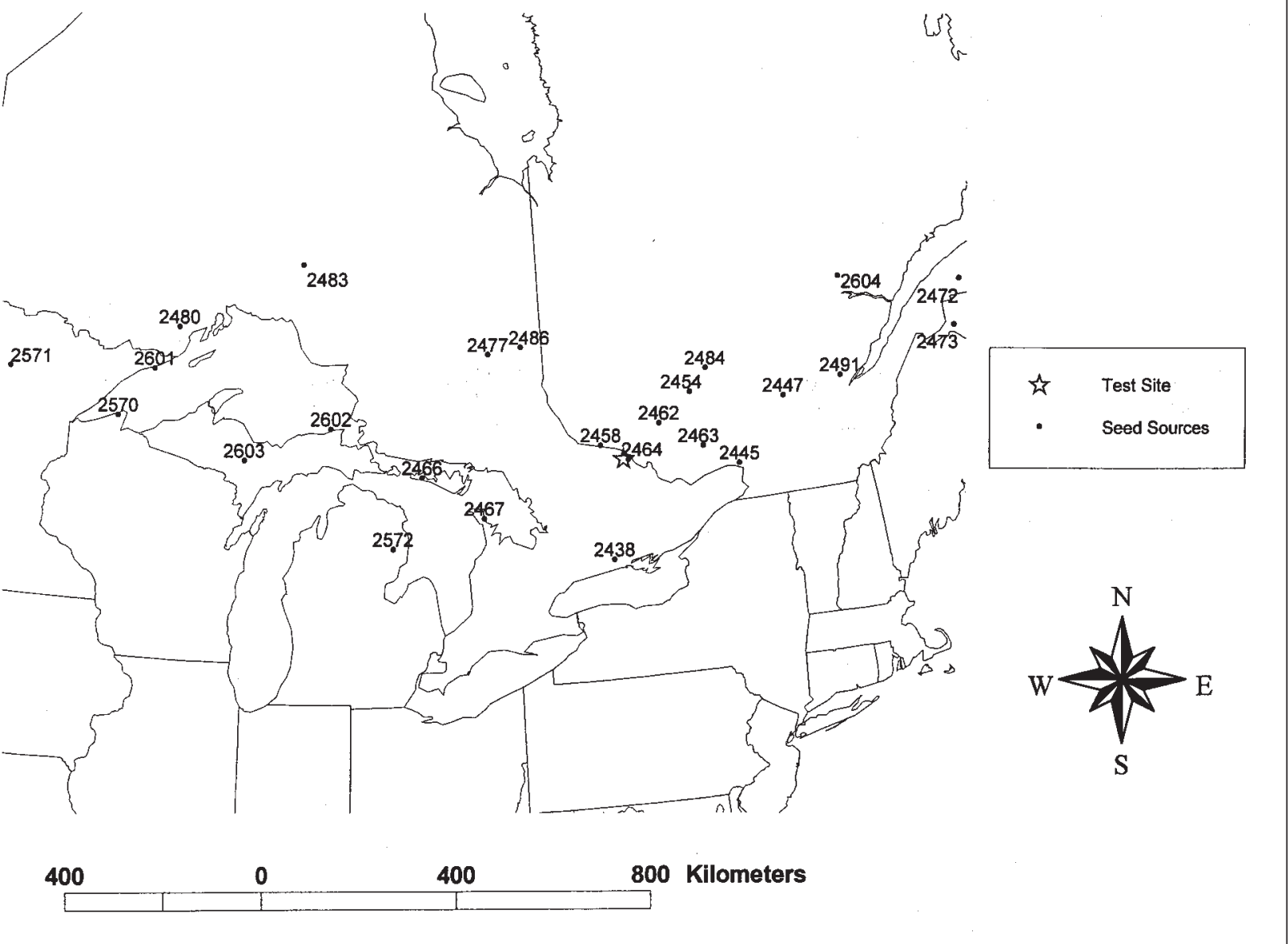

Fig. 1. Provenance origin in eastern Canada and the Lake States of USA (map courtesy of Dr. W.H. Parker).

The plantation grew well and was maintained by removal of competing vegetation. The first assessments were made in 1968 (age 10 years from seed) and 1973 (age 15) including total height and survival \% (Teich 1973, Teich et al. 1975). As part of the western series, results from this experiment were also reported by Murray and Skeates (1985), and by Morgenstern and Copis (1999). In 1986 (age 26), every second tree in each row was removed by diagonal thinning, leaving 72 trees per plot if all had survived.

In this paper we report on results obtained in 2002 when the trees were 44 years old, and also use some of the 15-year results for comparison purposes. The 2002 measurements and survival counts were made on a maximum of the inner core 50 trees per plot (i.e., 1500 trees if extrapolated to a perhectare basis). The following characteristics were assessed: survival percent, mean height, dominant height (the average height of the 20 trees per plot with the largest diameter), diameter at breast height (DBH) of all trees, basal area (BA) in square meters per hectare (ha), and wood volume in cubic meters per ha.

Heights were measured using a Criterion 400 Survey Laser instrument (manufactured by Laser Technology Inc.) on about half the trees in each plot, which were randomly selected by diameter classes. Using these data, a separate height-diameter equation was calculated for each plot to estimate the height of the remaining trees based on the following variation of the Bertalanffy equation (Pinaar and Turnbull 1973):

[1] $h t=1.3+\beta_{o} \cdot\left(1-e^{-\beta_{1} \cdot D B H}\right) \beta_{2}$

where $\beta_{o}, \beta_{1}$ and $\beta_{S}$ are parameters to be estimated

Volumes were then estimated from equation 14 of Honer et al. (1983).

The statistical analyses included analyses of variance and correlation analyses. The analyses of variance at age 44 were based on plot means and included survival, mean height, diameter, basal area, and volume. We assumed a random model and used the randomized complete-block analysis (Steel and Torrie 1960). For survival, percentages were transformed by arcsin from Table A.10 of Steel and Torrie (1960) to meet the requirements of a normal distribution. The correlations were computed from a table of overall means.

The final procedure was the identification of the eight best provenances. From an inspection of the volumes calculated, one top provenance was recognized followed by a cluster of 
Table 2. Provenance means over all replications for eight characteristics

\begin{tabular}{|c|c|c|c|c|c|c|c|c|}
\hline \multirow[b]{2}{*}{ Seed Lot No. } & \multicolumn{2}{|c|}{ Age 15} & \multicolumn{6}{|c|}{ Age 44} \\
\hline & $\begin{array}{c}\text { Survival } \\
\%\end{array}$ & $\begin{array}{l}\text { Height } \\
\mathrm{cm}\end{array}$ & $\begin{array}{c}\text { Survival } \\
\%\end{array}$ & $\begin{array}{l}\text { Av. height } \\
\text { m }\end{array}$ & $\begin{array}{c}\text { Dom. height } \\
\text { m }\end{array}$ & $\begin{array}{c}\mathrm{DBH} \\
\mathrm{cm}\end{array}$ & $\begin{array}{c}\mathrm{BA} \\
\mathrm{m}^{2} / \mathrm{ha}\end{array}$ & $\begin{array}{l}\text { Volume } \\
\mathrm{m}^{3} / \mathrm{ha}\end{array}$ \\
\hline 2438 & 88 & 335 & 77 & 15.2 & 16.8 & 18.8 & 34.6 & 240.1 \\
\hline 2445 & 88 & 301 & 78 & 15.8 & 17.3 & 19.7 & 40.1 & 287.3 \\
\hline 2447 & 86 & 324 & 81 & 15.3 & 16.8 & 18.6 & 37.4 & 261.4 \\
\hline 2454 & 89 & 315 & 77 & 15.0 & 16.8 & 19.0 & 35.9 & 248.9 \\
\hline 2458 & 92 & 309 & 81 & 14.6 & 16.2 & 18.2 & 34.7 & 231.0 \\
\hline 2462 & 83 & 269 & 79 & 15.3 & 16.8 & 18.9 & 36.9 & 256.8 \\
\hline 2463 & 86 & 341 & 78 & 15.3 & 16.9 & 19.3 & 37.5 & 263.2 \\
\hline 2464 & 88 & 306 & 78 & 16.0 & 17.6 & 18.9 & 36.0 & 259.1 \\
\hline 2466 & 94 & 306 & 79 & 13.9 & 15.6 & 17.8 & 31.8 & 207.5 \\
\hline 2467 & 81 & 283 & 73 & 14.1 & 15.3 & 18.5 & 30.2 & 195.7 \\
\hline 2472 & 86 & 269 & 78 & 14.4 & 15.9 & 18.8 & 36.0 & 238.1 \\
\hline 2473 & 90 & 301 & 80 & 15.0 & 16.4 & 19.0 & 38.2 & 259.2 \\
\hline 2477 & 96 & 266 & 75 & 15.4 & 17.3 & 18.5 & 31.8 & 224.0 \\
\hline 2480 & 85 & 257 & 79 & 14.1 & 15.9 & 18.0 & 32.9 & 216.7 \\
\hline 2483 & 89 & 237 & 79 & 13.5 & 15.1 & 17.6 & 31.2 & 196.3 \\
\hline 2484 & 83 & 280 & 76 & 14.5 & 15.9 & 18.7 & 33.1 & 220.4 \\
\hline 2486 & 83 & 321 & 76 & 15.4 & 17.0 & 18.8 & 33.8 & 237.3 \\
\hline 2491 & 92 & 269 & 80 & 14.7 & 16.4 & 18.9 & 37.4 & 254.0 \\
\hline 2570 & 77 & 280 & 80 & 15.5 & 17.4 & 18.8 & 36.5 & 259.0 \\
\hline 2571 & 83 & 298 & 75 & 15.2 & 16.8 & 18.6 & 32.3 & 224.1 \\
\hline 2572 & 75 & 283 & 72 & 14.7 & 16.0 & 19.0 & 31.3 & 208.6 \\
\hline 2601 & 75 & 280 & 76 & 13.8 & 15.5 & 17.5 & 29.2 & 189.1 \\
\hline 2602 & 86 & 295 & 73 & 13.7 & 14.8 & 18.9 & 31.8 & 201.4 \\
\hline 2603 & 90 & 251 & 75 & 14.2 & 15.7 & 19.0 & 33.6 & 221.7 \\
\hline 2604 & 82 & 237 & 75 & 14.2 & 15.5 & 18.5 & 31.7 & 206.3 \\
\hline Mean & 86 & 289 & 77 & 14.8 & 16.3 & 18.7 & 34.2 & 232.3 \\
\hline
\end{tabular}

Table 3. Mean squares (M.S.) and F-values (F) from the analyses of variance at age $44^{\mathrm{a}}$

\begin{tabular}{|c|c|c|c|c|c|c|c|c|c|c|}
\hline \multirow[b]{2}{*}{ Source } & \multicolumn{2}{|c|}{ Survival } & \multicolumn{2}{|c|}{ Mean height } & \multicolumn{2}{|c|}{ Diameter } & \multicolumn{2}{|c|}{ Basal area } & \multicolumn{2}{|c|}{ Volume } \\
\hline & M.S. & $\mathrm{F}$ & M.S. & $\mathrm{F}$ & M.S. & $\mathrm{F}$ & M.S. & $\mathrm{F}$ & M.S. & $\mathrm{F}$ \\
\hline Provenances d.f. $=24$ & 52.45 & $1.76^{*}$ & 2.05 & $5.54^{* *}$ & 1.71 & $2.48^{\star *}$ & 37.88 & $4.91^{\star \star}$ & 2816 & $3.09^{* *}$ \\
\hline d.f. $=2$ & 7.16 & 0.24 & 3.16 & $8.54^{* *}$ & 0.90 & 1.30 & 11.71 & 1.52 & 664 & 0.73 \\
\hline d.f. $=48$ & 29.86 & & 0.37 & & 0.69 & & 7.72 & & 910 & \\
\hline
\end{tabular}

aSignificance levels: ${ }^{\star}, 5 \% ;{ }^{\star *}, 1 \%$ and higher.

Table 4. Pearson correlation coefficients among seven characteristics at ages 15 and 44 , and latitude of origina

\begin{tabular}{|c|c|c|c|c|c|c|c|c|c|}
\hline & & $\mathrm{X}_{1}$ & $\mathrm{X}_{2}$ & $\mathrm{X}_{3}$ & $\mathrm{X}_{4}$ & $X_{5}$ & $\mathrm{X}_{6}$ & $\mathrm{X}_{7}$ & $\mathrm{X}_{8}$ \\
\hline$X_{1}$ & Survival $_{15}$ & 1.00 & 0.38 & -0.05 & 0.10 & 0.03 & 0.29 & 0.24 & 0.08 \\
\hline $\mathrm{X}_{2}^{1}$ & Survival $_{44}$ & & 1.00 & 0.11 & 0.22 & -0.13 & $0.62^{\star *}$ & $0.54^{\star \star}$ & 0.24 \\
\hline $\mathrm{X}_{3}^{2}$ & Height $_{15}{ }^{44}$ & & & 1.00 & $0.49^{*}$ & 0.35 & 0.36 & $0.43^{*}$ & $-0.48^{*}$ \\
\hline $\mathrm{X}_{4}$ & Height $_{44}$ & & & & 1.00 & $0.65^{\star *}$ & $0.67^{\star *}$ & $0.83^{\star \star}$ & -0.27 \\
\hline$X_{5}^{4}$ & $\mathrm{DBH}_{44}^{44}$ & & & & & 1.00 & $0.69^{* *}$ & $0.71^{* *}$ & $-0.44^{*}$ \\
\hline $\mathrm{X}_{6}$ & $\mathrm{BA}_{44}$ & & & & & & 1.00 & $0.97^{* \star}$ & -0.14 \\
\hline $\mathrm{X}_{7}$ & $\mathrm{Vol}_{44}$ & & & & & & & 1.00 & -0.19 \\
\hline $\mathrm{X}_{8}^{\prime}$ & Latitude & & & & & & & & 1.00 \\
\hline
\end{tabular}

aSignificance levels: ${ }^{\star}, 5 \%$; ${ }^{\star *}, 1 \%$ (23 d.f.) 
Table 5. The top eight provenances when ranked at ages 15 and 44 for several characteristics according to a point system.

\begin{tabular}{|c|c|c|c|c|c|c|c|c|c|}
\hline \multirow{2}{*}{\multicolumn{2}{|c|}{$\begin{array}{l}\text { Age } 15 \\
\text { Height }\end{array}$}} & \multicolumn{8}{|c|}{ Age 44} \\
\hline & & \multicolumn{2}{|l|}{ Height } & \multicolumn{2}{|l|}{ Survival } & Volume & \multicolumn{3}{|c|}{ Survival \& Volume Combined } \\
\hline Provenance & & Provenance & oints & Provenance & Points & Provenance & & Provenance & Points \\
\hline Notre-Dame-du-Laus & 1 & Chalk River & 1 & Grandes-Piles & 1 & Cushing & 1 & Grandes-Piles & 4 \\
\hline Cobourg & 2 & Cushing & 2 & Bissett Creek & 1 & Notre-Dame-du-Laus & 2 & Cushing & 5 \\
\hline Grandes-Piles & 3 & Chequamegon & 3 & Edmundston & 2 & Grandes-Piles & 3 & Notre-Dame-du-Laus & 1s 6 \\
\hline Swastika & 4 & Ashley Mines & 4 & Valcartier & 2 & Chalk River & 4 & Edmundston & 6 \\
\hline Lac Baskatong & 5 & Swastika & 4 & Chequamegon & 2 & Edmundston & 4 & Chequamegon & 8 \\
\hline Bissett Creek & 6 & Notre-Dame-du-Laus & 5 & Lac McNally & 3 & Chequamegon & 4 & Chalk River & 9 \\
\hline Chalk River & 7 & Grandes -Piles & 5 & Manitoulin Island & 3 & Lac McNally & 5 & Lac McNally & 10 \\
\hline Manitoulin Island & 7 & Lac McNally & 5 & Kakabeka & 3 & Valcartier & 6 & Valcartier & 10 \\
\hline
\end{tabular}

seven provenances with minor differences and then a substantial drop in the remainder. As a result, the best eight provenances were identified at every stage and a point system used assigning points 1, 2, 3 to the first-, second-, and thirdhighest ranking provenances, etc. and the sum of individual points when the ranking was based on the combined value of two characteristics, such as survival and volume.

\section{Results}

A summary of results in the form of provenance means over all replications at ages 15 and 44 from seed is given in Table 2 . The 15-year data were taken from Tables 5 and 6 of Teich et al. (1975). The results of the analysis of variance at age 44 for survival, mean height, diameter, basal area and volume are presented in Table 3. Correlation coefficients for all seven characteristics and latitude of origin are shown in Table 4, and a list of the eight best provenances in Table 5.

\section{General observation}

The growth of the plantation reflects a site of intermediate productivity. The local provenance, S.2464, Chalk River, had reached an average height of $16.0 \mathrm{~m}$, dominant height of $17.6 \mathrm{~m}$, basal area of $36.0 \mathrm{~m}^{2}$ and volume of $259 \mathrm{~m}^{3}$ (Table 2). It exceeded the plantation average in every characteristic. When compared with figures in a local yield table (Berry 1978), it ranks somewhere between Site Class 18 and 21 where 15 is the lowest and 24 the highest class. In contrast to earlier impressions, this is only an average site and growth was not as rapid as expected on the basis of earlier observations.

\section{Survival}

At age 15 , mean survival was $86 \%$ and there was no significant difference among provenances at the $5 \%$ level (Teich et al. 1975). By age 44 it had declined only $9 \%$ to $77 \%$ and the differences had become significant at the $5 \%$ level according to the analysis of variance (Table 3 ). Correlations were significant between age 44 survival and basal area and volume (Table 4).

\section{Height}

At age 15, mean height had differed significantly only at the extremely low level of $25 \%$ as shown by Teich et al. (1975) in their Table 2 but by age 44 had differentiated much and was significant at $0.01 \%$ (higher level than shown in Table 3).
Correlations were significant between height at age 15 and height at 44, and between height at 15 and volume, and height at 44 and diameter, basal area, and volume. Correlations between latitude and height were always negative and significant only at age 15 (Table 4).

\section{Diameter}

Diameters differed significantly among provenances at the $1 \%$ level (Table 3 ). As expected, they are strongly correlated with basal area and volume (Table 4).

\section{Basal area}

Basal area ranged from 29.2 to $40.1 \mathrm{~m}^{2}$ per ha (Table 2) and differed significantly among provenances at the $1 \%$ level (Table 3).

\section{Volume}

Volume ranged from 189 to $287 \mathrm{~m}^{3}$ per ha and differed significantly at the $1 \%$ level (Tables 2 and 3). The top ranking provenance, S.2445, Cushing, with $287 \mathrm{~m}^{3}$, exceeded the local, S.2464, Chalk River with $259 \mathrm{~m}^{3}$ by $10.8 \%$.

\section{Discussion}

It is a well-known principle of genetic and yield studies that favourable environments accelerate growth and differentiation. Consequently, this experiment, on an average site, can be expected to develop greater differences in survival and volume during the next one or two decades. For this reason it should be maintained and protected for some time to come.

A second important principle of provenance research is that statistical tests of significance are not independent of sampling and field testing. In short-term studies, when many provenances can be grown in a small area, clinal variation in phenology and growth in response to natural selection by photoperiod and temperature is commonly observed and confirmed by significant correlations in our northern, widely distributed conifers (Morgenstern 1996). This correlation is strongest with the weekly decline in day length between the longest day, 21 June and the day of the fall equinox, 23 September (Withrow 1959). In contrast, in long-term field experiments with greater environmental confounding influences, this clinal trend is not always detected. In this experiment, particularly, it is therefore not surprising that this trend is only weakly expressed by negative, usually non-significant 
correlations with latitude (Table 4). The fact that the southnorth distribution of the provenances sampled is relatively narrow may also be involved (Fig. 1).

There is a substantial difference between early and late results. At age 15, height was only correlated at the 5\% level with height at 44 and with volume (Table 3 ). Only four of the eight tallest provenances at age 15 were also among the tallest at age 44 (Table 5). Significant differences in survival were not detected until age 44 (Table 3 ).

The eight best provenances with greatest survival and volume come primarily from southeastern Quebec and the Ottawa Valley in Quebec and Ontario. Exceptions are Edmundston, New Brunswick, and Chequamegon, Wisconsin, United States. Most of these provenances originated from areas within 1 to 1.5 degrees of latitude from the test site (Tables 1,2,5). The excellent performance of Cushing is of special interest because it confirms the existence of vigorous populations in the Ottawa Valley east of the Petawawa Research Forest. Another Ottawa Valley provenance from Beachburg performed very well in several companion experiments of the 194 series (Teich et al. 1975), and it was the top performer at the 14 test sites in the Lake States and New Brunswick in a cooperative series initiated by the U.S. Forest Service (Nienstaedt 1969, Nienstaedt and Teich 1972). For this reason the Petawawa National Forestry Institute selected several hundred plus trees in many stands in the area east of Pembroke and established a clonal seed orchard (Murray and Cheliak 1984). Provenances from this area were also included in the new range-wide test series established between 1979 and 1984 (Ying 1980), which has already yielded results to study potential effects of climate change and carbon sequestration (Cherry and Parker 2003).

The two southernmost provenances, Cobourg (lat. $44.1^{\circ} \mathrm{N}$ ) and Huron National Forest (lat. $44.5^{\circ} \mathrm{N}$ ) have not been growing well and are in 10th and 19th position for volume (Table 2). From two tests, one on a granitic (acid) site at Petawawa, and another on a limestone site at Lake Dore $56 \mathrm{~km}$ to the south, Teich and Holst (1974) obtained a significant provenance-site interaction, and proposed an ecotype hypothesis. The limestone-origin provenances grow better on the limestone site and the granitic-origin provenances performed better on the granitic site. Cobourg is a limestone-origin provenance. How general this hypothesis applies is not known. In another sample of provenances, Lesser et al. (2004) could not confirm the hypothesis.

Another plausible theory is inbreeding: disjunct or isolated small populations mate with close relatives and become less variable and more narrowly adapted. This theory has merit because low levels of inbreeding are not rare in this species (Coles and Fowler 1976), and the Cobourg area stands are definitely small and isolated.

\section{Conclusion}

This test has contributed valuable information with respect to provenance origin. The excellent performance of Cushing, Que. is further evidence for the existence of fast-growing populations in the Ottawa Valley.

The history of this experiment contains important lessons with respect to experimental design. Shortly after this experimental series was established across Ontario, difficulties with these large inflexible square plots and blocks became evident during layout and maintenance. At the same time, a very influential paper (Wright and Freeland 1960) stressed the advantage of many replications and small plots. In consequence, the next white spruce test series was redesigned and smaller plots were adopted. Unfortunately, the cited authors had focussed attention on one test environment only and neglected the fact that each experiment should have at least two test environments in the same region to determine the provenance-environment interaction. In that situation, the error variance (which determines statistical efficiency) is calculated from all replications over all environments, i.e., it is a pooled error. In such a situation, experience has shown that it is usually more efficient to include more environments with fewer replications than vice versa, so that often two or three replications per environment are sufficient (Loo-Dinkins 1992, Morgenstern 1996). In addition, large square plots have advantages because they yield results independent of plot-toplot competition and allow for calculations on a per-unit area basis and are therefore much more useful for long-term studies than row-plots. It is now important to learn that lesson.

\section{Acknowledgements}

This paper has benefited from two anonymous reviewers, and the suggestions of Dr. William H. Parker, Lakehead University, and Dr. Jean Beaulieu, Canadian Forest Service, are gratefully acknowledged. Dr. Parker also contributed Fig. 1.

\section{References}

Beaulieu, J., M. Perron and J. Bousquet. 2004. Multivariate patterns of adaptive genetic variation and seed source transfer in Picea mariana. Can. J. For. Res. 34: 531-545.

Berry, A.B. 1978. Metric yield tables based on site class and spacing for white spruce plantations at the Petawawa Forest Experiment Station. Can. For. Serv. Inf. Rep. PS-X-70. 15 p.

Cherry, M. and W.H. Parker. 2003. Utilization of genetically improved stock to increase carbon sequestration. Ont. Min. Nat. Res. For. Res. Rep. 160.15 p.

Cochrane, W.G. and G.M. Cox. 1957. Experimental designs. 2nd. ed. Wiley \& Sons, New York.

Coles, J.F. and D.P. Fowler. 1976. Inbreeding in neighboring trees in two white spruce populations. Silvae Genet. 25: 29-34.

Corriveau, A. and M. Boudoux. 1971. Le développement des provenances d'épinette blanche de la région forestière des Grands-Lacs et du St. Laurent au Québec. Serv. Can. For. Rap. d'Info. Q-F-X.15. 38 p.

Honer, T.G., M.F. Ker and I.S. Alemdag. 1983. Metric timber tables for the commercial tree species of central and eastern Canada. Can. For. Serv. Inf. Rep. M-X-140. 139 p.

Holst, M.J. 1958. Our co-operative white spruce provenance experiment. Unpubl. manuscript, Dept. North. Affairs and National Resources, Forest Research Division, Petawawa Forest Experiment Station. 14 p.

Lesser, M.R., M. Cherry and W.H. Parker. 2004. Investigation of limestone ecotypes of white spruce based on a provenance test series. Can. J. For. Res. 34: 1119-1127.

Loo-Dinkins, J. 1992. Field test design. In L. Fins, S.T. Friedman and J.V. Brotschol (eds.). Handbook of quantitative forest genetics. pp. 96-139. Forestry Science, Vol 39, Kluwer Academic Publishers. 403 p. Morgenstern, E.K. 1969. Genetic variation in seedlings of Picea mariana (Mill.) B.S.P. Silvae Genet. 18: 151-67.

Morgenstern, E.K. 1996. Geographic variation in forest trees. UBC Press, Vancouver. 209 p.

Morgenstern, E.K. and P. Copis. 1999. Best white spruce provenances in Canada. Can. For. Serv. Inf. Rep. ST-X-16. 34 p.

Murray, G. and W. Cheliak. 1984. Genetics of white spruce, larches and hardwoods. Proc. Nineteenth Meeting Can. Tree Improv. Assoc., Pt. 1.pp. 130-132. 
Murray, G. and D.A. Skeates. 1985. Variation in height of white spruce provenances after 10 and 20 years in five field tests. Proc. 29th Northeast. For. Tree Improv. Conf., West Virginia Univ., Morgantown, WVA., July 18-20, 1984. Pp. 82-89.

Nienstaedt, H. 1969. White spruce seed source variation and adaptation to 14 planting sites in northeastern United States and Canada. Proc. Eleventh Meeting Committee on Forest Tree Breeding in Canada, pp. 183-194.

Nienstaedt, H. and A. Teich. 1972. The genetics of white spruce. U.S. For. Serv. Res. Pap. WO-15. 24 p.

Oleksyn, J. and M. Giertych. 1984. Results of a 70 year old Scots pine (Pinus sylvestris L.) provenance experiment in Pulawy, Poland. Silvae Genet. 33: 22-27.

Pinaar, L.V. and K.J. Turnbull. 1973. The Chapman-Richards generalization of Von Bertalanffy's growth model for basal area growth and yield in even-aged stands. For. Sci. 19: 2-22.

Rehfeldt, G.E. 2004. Interspecific and intraspecific variation in Picea engelmannii and its cogeneric cohorts: biosytematics, genecology, and climate change. U.S. Dept. Agric., Forest Service Gen. Tech. Rep. RMRS-GRT-134. 18 p.

Rowe, J.S. 1959. Forest regions of Canada. Dept. Northern Affairs and National Res., For. Br. Bull. 123. 71 p + map.
Schober, R. 1961. Zweckbestimmung, Methodik, und Vorbereitung von Provenienzversuchen. (Purposes, methodology and preparation of provenance experiments). Allgem. Forst-und Jagdztg. 132: 29-38. Silen, R. 1978. Genetics of Douglas-fir. U.S. For. Serv. Res. Pap. WO$35.34 \mathrm{p}$.

Steel, R.G.D. and J.H. Torrie. 1960. Principles and procedures of statistics. McGraw-Hill Book Co. Inc., New York. 481 p.

Teich, A.H. 1973. White spruce provenances in Canada. Can. For. Serv. Inf. Rep. PS-X-40. 6 p. + tables.

Teich, A.H. and M.J. Holst. 1974. White spruce limestone ecotypes. For. Chron. 50: 110-111.

Teich, A.H., D.A. Skeates and E.K. Morgenstern. 1975. Performance of white spruce provenances in Ontario. Can. For. Serv. and Ont. Min. Nat. Res. Special Joint Rep. No. 1. 30 p.

Withrow, R.B. (ed.). 1959. Photoperiodism and related phenomena in plants and animals. Am. Assoc. Adv. Sci. Pub. 55. 903 p.

Wright, J.W. and F.D. Freeland. 1960. Plot size and experimental efficiency in forest genetic research. Michigan State Univ., Agric. Exp. Sta., Dept. of Forestry, Tech. Bull. 280. 28 p.

Ying, C.C. 1980. White spruce genetics, Petawawa 1977-1978. Proc. Seventeenth Meeting, Can. Tree Improv. Assoc., Pt. 1. pp. 169-171. 